\section{BSE survelllance and safety measures still found wanting}

[PARIS] One year after the United Kingdom announced a possible link between bovine spongiform encephalopathy (BSE) and Creutzfeldt-Jakob disease, many member states of the European Union have still not taken adequate steps to detect BSE or to prevent a further spread of the disease.

This is the conclusion of an internal European Commission document, Risk factors and surveillance with regard to BSE in the community, based on short inspections in 13 member states last autumn (the United Kingdom and Portugal were evaluated separately).

The report says the quality of surveillance systems for detecting BSE cases varies widely, while the fact that farmers are not always compensated in full for declaring cases acts as a disincentive. It calls for laboratory examination of all suspected BSE cases, complete record-keeping, and better training. The commission should establish a reference laboratory to ensure uniform application of standardized procedures, it adds.

The number of expected cases of BSE in continental Europe has been estimated at several thousand - although only a few hundred cases have been officially reported (see Nature 382, 4; 1996). This does not mean that an epidemic is going unreported, emphasizes a commission official but, rather, that there is a need to have good systems in place as a preventive measure.

Of more immediate concern is the risk that even low levels of BSE could increase because of insufficient controls on the animal feed in which the disease is transmitted. The European Commission has introduced a ban on feeding mammalian protein to ruminants, but its inspectors found that feed labelled as containing no meat or bone meal often contained as much as 5 per cent.

The most likely explanation is crosscontamination - most feed mills use the same equipment to produce all feed, so meal destined for pig and poultry feed can find its way into cattle feed. One commission official says that the only solution is either to have separate mills for pig and poultry rations and for ruminant feed - as is happening in Ireland - or to ban mammalian protein from the feed of all farm animals, a step taken belatedly in the United Kingdom last March.

Most member states say they are implementing a European Commission directive stipulating that rendering plants must convert to batch-processing at $130^{\circ} \mathrm{C}$ and 3 bars pressure for at least 20 minutes. But many are behind in doing so, while France insists its existing arrangements are adequate. Inspectors found evidence of non-compliance with procedures in several states.

\title{
'Poor security' blamed for loss of Russian fossils
}

[MOSCOW] A meeting of the biology section of the Russian Academy of Sciences was told last week that the disappearance of specimens from the academy's botanical, zoological and palaeontological collections has been largely the result of lack of funds for proper security measures.

The meeting was held to respond to allegations that dinosaur skulls missing from the academy's Institute of Palaeontology in Moscow may have been smuggled out of the country (see Nature 384, 499; 1996).

It discussed a resolution drawn up by three corresponding members of the academy which stated that, although the institution's collections were of substantial scientific and cultural value, insufficient funds for security had resulted in numerous thefts.

But the meeting failed to adopt the resolution, which attempted to respond to the smuggling charges by criticizing foreign researchers for holding on to specimens from the institute's collections for longer than had been agreed.

The panel confirmed that the palaeontology institute has lost 23 amphibian skulls, two mammoth tusks and an ammonite collection, in addition to three dinosaur skulls and two jaws which disappeared last year.

But the institute is not alone in experiencing losses. Between 1992 and 1996, for example, the Zoological Institute in St Petersburg lost articles made of mammoth tusk, three rhinoceros horns and one mammoth tooth, as well as 13 species of tropical beetles. Rare wood and tobacco specimens have disappeared from a botanical museum as well as a sculpture weighing more than $120 \mathrm{~kg}$.

The authors of the draft resolution blame what they describe as "the imperfection" of Russian law which "prevents control of the biological objects market, and attracts to it criminal elements". They also claim that a "special problem" is the refusal of some Western specialists to return items loaned to them - naming in particular scientists at the University of Bristol in the United Kingdom.

But one of the UK researchers concerned dismisses such charges, pointing out that the Bristol group had been informed by the institute that there would be "no problem" in holding on to the specimens because one of the researchers is a Russian national who is being supported by the Royal Society.

Aleksei Rozanov, director of the Institute of Palaeontology, and his deputy, Igor Novikov, claimed that accusations that staff from the institute may have been involved in the disappearance of specimens was "unfair".

But Vladimir Sokolov, chairman of the academy's biology section, who chaired the

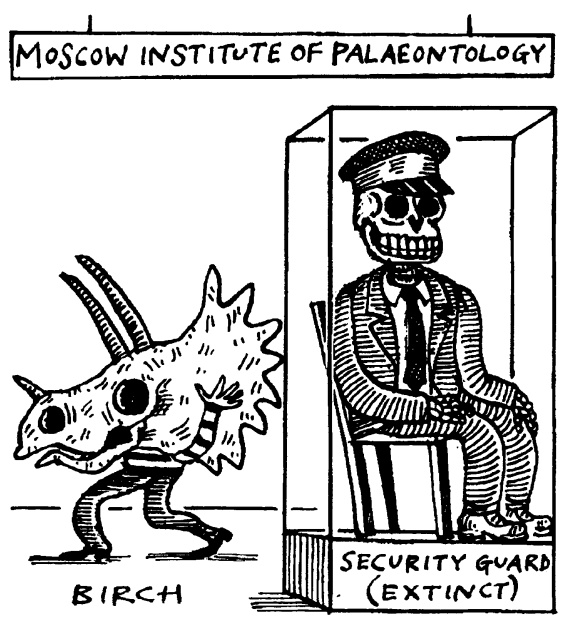

meeting, asked Novikov, "how could it happen that an internationally known scientific body did not protect its reputation?". On the question of loans to Western institutions, he said that he was unable to believe the situation as it had been reported.

Novikov said that the failure to return specimens on time is a worldwide practice, admitting that Russian scientists sometimes keep foreign material for years longer than agreed. He also reported that one of the two dinosaur jaws that he had earlier declared to be missing has since been found in the museum.

Rozanov told the meeting that the institute had lost hope that either the national or international police forces could help, and that this was why neither had been contacted about the latest thefts. "Instead we made direct contact with customs authorities to try to prevent the fossils leaving Russia illegally."

According to Rozanov, the power of the black market in this field is such that he was not willing to name the institute official who was in touch with the customs authorities for fear that he might be killed. He said that shortage of money meant that unofficial contacts were the only way open to the institute to address the problem.

Only after the first thefts had money been found to provide museum showcases with locks, and a basic alarm system had not been installed until 1995. (The equally valuable museum of the St Petersburg Zoological Institute still has no alarm.) A sum of US $\$ 167,000$ is needed to ensure the safety of the collections in the Institute of Palaeontology.

Alexei Yablokov, head of the Centre for Russian Environment Policy, whose call for steps to protect the collections had prompted the meeting, said he believed that further measures were needed.

CarlLevitin 